UDC $581.132+577.118$

\title{
INFLUENCE OF TRACE ELEMENTS, APPLIED IN CLASSICAL AND NANO FORMS, ON PHOTOSYNTHESIS OF HIGHER PLANTS IN RELATION TO ENHANCEMENT OF CROP PRODUCTIVITY
}

\author{
G. O. Priadkina \\ Institute of Plant Physiology and Genetics NAS of Ukraine, \\ 31/17, Vasylkivska Str., Kyiv, Ukraine, 03022 \\ E-mail:galpryadk@gmail.com
}

Received March 24, 2020 / Received May 05, 2020 / Accepted November 20, 2020

\begin{abstract}
One of the main factors of increasing the productivity of agricultural plants is intensifying the activity of the photosynthetic apparatus, since the productivity of crops depends on the ability to absorb solar radiation and convert it into the energy of chemical bonds for further use in metabolic processes. The amount of photosynthetically active radiation absorbed by crops, in its turn, depends on the area, duration, and activity of the assimilation surface functioning. The use of fertilizers, that contain trace elements, can further achieve both raising the yield of cultivated plants and environmental protection. In this regard, the state-of-the-art research on the influence of the main trace elements (iron, zinc, manganese, molybdenum, cobalt, selenium, boron, titanium) and one macroelement - magnesium - on photosynthetic characteristics of plants and crops is discussed. Based on the literature data and the results of our own research, we documented the effect of trace elements on leaves carbon dioxide exchange rates, the content of photosynthetic pigments, the antioxidant enzymes activity, as well as the traits of the photosynthetic apparatus capacity. The influence of nanometals on the content and ratio of pigments, net $\mathrm{CO}_{2}$ assimilation rate, and the photochemical activity of photosystems, including the effect of stress factors, is discussed. The specificities of the influence of nanometals are discussed and possible mechanisms of the effect of low concentrations of trace elements on plant metabolism are analyzed. It is shown that trace elements influence photosynthetic processes in plants and the systems of their antioxidant protection. The relevance of trace elements in the development of new strategies to elaborate the technologies of cultivating next-generation plants, including those that will be based on new physical and chemical properties of macro- and micronutrients in a nano form, is highlighted.
\end{abstract}

Key words: nanometals, photosynthetic pigments, antioxidant enzymes, $\mathrm{CO}_{2}$ assimilation.

DOI: https://doi.org/10.15407/agrisp7.03.071

Food problems take a special place among the major global challenges. The demand for the staple foods has already exceeded the increase in the yield which indicates possible shortage of food even in the middle of the $21^{\text {st }}$ century (Long SP et al, 2015). The aggravation of the food problem in current conditions is conditioned by many social and economic factors (Ray DK et al, 2012; Long SP and Ort DR, 2010; Presidential Commission 2012). For instance, the share of arable lands in the world increased from 10.4 to $11.06 \%$ i.e. only by fractions of one per cent, within 1970-2016 (https://data.worldbank.org/). In addition, the share of agricultural products, used as biofuel, increases as

(C) G. O. PRIADKINA, 2020 well (https://unctad.org/system/). Higher yield of cereals, demonstrated since the beginning of this century, is partially invalidated by agronomic factors, related to the economic policy: scaling down the use of legumes in crop rotations and a tendency to reduce the norms of introducing fertilizers in different countries (Brisson $\mathrm{N}$ et al, 2010; Zhang FS et al, 2013; Zander $\mathrm{P}$ et al, 2016; Lesk C et al, 2016). The situation with food provision for humanity is further deteriorated by climatic changes. Modern climate is characterized by more frequent incidents of unfavorable weather conditions which diminish the productivity of plants (Lesk C et al, 2016). For instance, according to the data of the European Commission, a considerable loss in the yield of wheat (10-78 \%) in Europe since the beginning of the 
$21^{\text {st }}$ century was mainly caused by drought and heavy precipitation (https://ec.europa.eu).

Therefore, current efforts of many scientific institutions are focused on searching for new efficient ways of determining the possibilities to increase the yield of agricultural plants in modern conditions. The enhanced photosynthetic efficiency is believed to be the most promising trend of the mentioned investigations ( $\mathrm{Zhu}$ XG et al, 2010; Parry MAJ et al, 2011; Reynolds M et al, 2011; Morales F et al, 2020). It is conditioned by the main role of the photosynthesis process in forming biomass and productivity of plants: about $90 \%$ of shoot dry weight of plants are formed due to the photosynthetic $\mathrm{CO}_{2}$ assimilation (Evans LT et al, 1975; Beadle CL and Long SP, 1985). It was demonstrated for many modern species of agricultural plants that the increased yield was accompanied with higher intensity of photosynthesis per leaf unit. For instance, the photosynthesis rate in winter wheat cultivars, created in the 1990 s, was $40 \%$ higher per leaf area unit compared to the ones, created in the 1950 s, and grain productivity was $36-800 \%$ higher (Jiang $\mathrm{GM}$ et al, 2003). It was also demonstrated that the rate of photosynthesis of winter wheat cultivars, bred in early $2000 \mathrm{~s}$, fluctuated from 17 to $22 \mu \mathrm{mol} / \mathrm{m}^{2} / \mathrm{s}$, and the yield - from 7,080 to $7,965 \mathrm{~kg} / \mathrm{ha}$, while in 1956-1965 - $11-14 \mu \mathrm{mol} / \mathrm{m}^{2} / \mathrm{s}$ and $2,255-3,577 \mathrm{~kg} / \mathrm{ha}$ respectively (Biswas DK et al, 2008). The increase in the rate of photosynthesis in soybeans cultivars (by $23 \%$ ), caused by higher concentration of $\mathrm{CO}_{2}$, was also accompanied with the yield growth from 4.6 to $5.3 \mathrm{t} / \mathrm{ha}$ (Morgan PB et al, 2005; Dermody O et al, 2008). In addition, highly productive cultivars differ in other indices, related to the activity of the photosynthetic apparatus, such as stomatal conductance of leaves, the activity of the main photosynthetic enzyme - ribulose bisphosphate carboxylaseoxygenase (Rubisco), the content and gross amount of chlorophyll (Priadkina GO, 2014).

The results of numerous studies demonstrate that the optimization of the functioning of photosynthetic apparatus promotes the rise in productivity of different species of plants (Long SP et al, 2015; Kromdijk J et al, 2016; Hubbart S et al, 2018; Zhu XG et al, 2020). It has recently been determined that the increase in the content of pigments (1.5-2-fold increase in chlorophylls and some xanthophylls) in tobacco lines with higher expression of lycopene beta-cyclase (DcLCYB ) from carrots led to $6-23 \%$ rise in the biomass of transgene lines (Moreno JC et al, 2020).

There is a discussion in the scientific literature about agronomic, physiological, and genetic ways of opti- mizing photosynthetic characteristics of plants and crops (Parry MAJ et al, 2011). The application of trace elements may be one of the options. It has been demonstrated that their positive effect on biomass formation and productivity varies from 10 to $70 \%$ depending on a trace element, presence, or absence of NPK (Dimkra CO and Bindraban PS, 2016). Their important role is related, firstly, to the fact that each of them is an irreplaceable mineral element, required to perform one or several functions. Trace elements are involved in various metabolic processes, including primary and secondary metabolism, energy exchange, protection of cells from oxidation, signal transmission, hormonal regulation, and regulation of genes (Marschner P, 2011; Kabata-Pendias A, 2011). Secondly, in drought conditions, which are more frequently observed during the vegetation development, there is lesser uptake of nutrients from soil and transport of metabolites from them to the aboveground part. The role of trace elements is also scaling up during the application of intense technologies, aimed at the formation of highly productive crops, which grow fast, require high doses of mineral nutrients, and remove a considerable amount of the latter from the soil (Morgun VV and Kiriziy DA, 2012). Therefore, intense uptake and therefore removal of trace elements by plants reduces their content in soil. At the same time, both deficiency and excess of trace elements may cause the impairment of biochemical and physiological processes in a plant (Marschner P, 2011; Andersen E et al, 2018; Vatansever R et al, 2017).

Thus, considering the significance of the photosynthesis process for the formation of biomass and plant productivity and the fact that the foliar fertilization for plants in current conditions becomes a vital element of the technologies of cultivating plants, we analyzed the results of investigations on the impact of the main microelements (iron, zinc, manganese, copper, molybdenum, cobalt and boron) on photosynthetic indices on different levels of the organization of photosynthetic apparatus. Considering an important function of one of the macroelements, magnesium $(\mathrm{Mg})$, in the processes, which take place in chloroplasts (within chlorophyll, synthesis of protoporphyrin IX, regulation of the structure of organellas, activity of the primary processes of photosynthesis) (Husted S et al, 2017; Tränker et al, 2018; Cakmak I and Marschner H, 1992), the impact of this trace element on photosynthetic indices was also analyzed.

The impact of trace elements on the indices of $\mathrm{CO}_{2}$ gas exchange. The studies of the impact of trace ele- 
ments on the main indices of $\mathrm{CO}_{2}$ gas exchange (the rate of photosynthesis, transpiration, stomatal conductance, intracellular $\mathrm{CO}_{2}$ concentration) in many species under different conditions are present in scientific literature. For instance, a 5-fold decrease in photosynthesis rate was determined for Barbados nut (Jatropha curcas L.) on the $105^{\text {th }}$ day of the experiment in the variant with iron deficiency compared to the control plants, cultivated with a complete mixture of nutrients (dos Santos et al, 2013). It was also demonstrated that on the $4^{\text {th }}$ day after treating French bean plants using iron with different ligands, the rate of $\mathrm{CO}_{2}$ gas exchange in their leaves increased by 16 $28 \%$ as compared to the control plants, treated with water (Borowski E and Mihalek S, 2011). It is believed that a reduction in photosynthesis rate under iron deficiency may be caused by the decrease in PS II activity, mainly via the impaired absorption of light in lightharvesting complexes and the decrease in the activity of the primary quinone acceptor of PS II - QA (Samborska-Skutnik IA et al, 2019). It was determined during field experiments with two different types of soils (alluvial and cinnamon ones) that both the introduction of different doses of zinc into soil and its combination with foliar treatment of plants had a positive effect on photosynthesis rate in corn leaves in all the experimental variants (Liu $\mathrm{H}$ et al, 2016). The increase in photosynthesis rate in winter wheat leaves was determined in the sand culture after the introduction of either molybdenum or zinc into soil or their combined application (Liu C et al, 2019). A similar effect of the application of zinc on $\mathrm{CO}_{2}$ gas exchange rate (a 1.5-fold increase, on average) was determined during a two-year field experiments with ten genotypes of Indian wheat (Bharti $\mathrm{K}$ et al, 2014).

A positive effect of trace elements on $\mathrm{CO}_{2}$ gas exchange was also demonstrated under the impact of stress factors of different etiology. For instance, on the background of low temperatures there was an increase in photosynthesis rate of two winter wheat lines which differed in their ability to absorb and accumulate Mo (Mo-efficient line 97003 and Mo-inefficient line 97014) - plants, treated with Mo, were compared against variants without any treatment (Sun X, 2006). Similar data on the photosynthesis rate increase in the plants, treated with Mo, under saline stress were obtained for Chinese cabbage plants (Zang M, 2012). Thus, it was determined that the treatment of plants with trace elements promotes the increase in photosynthesis rate under different stresses. In addition, the genotypic differences in the response of photosynthetic parameters to the impact of specific trace elements were determined. So, the photosynthesis and transpiration rates were much higher in Mo-efficient line plants, treated with molybdenum, compared to Mo-tolerant line (Wu SW, 2014). It was also demonstrated on different substrates (hydroponics, in vegetation pots and on lime-sandy soil) that old cultivars of Scotch barley (Bere barley) which absorb and accumulate Mn better, maintain a better state of photosynthetic apparatus compared to modern elite lines (Schmidt SB et al, 2019).

The effectiveness of the impact of trace elements (both introduction into soil and foliar treatment) on other indices of $\mathrm{CO}_{2}$ gas exchange was also determined. For instance, the improvement of stomatal conductance and transpiration of leaves in French beans was demonstrated after treating the plants using iron with organic and inorganic salts as ligands (Borowski $\mathrm{E}$ and Mihalek S, 2011). Simultaneous introduction of zinc into soil and its application in combination with foliar treatment of plants increased the transpiration rate in corn leaves considerably compared against the control variant ( $\mathrm{Liu} \mathrm{H}$ et al, 2016). On the contrary, under stress conditions (low temperatures) there was a decrease in the transpiration rate, stomatal conductance and intercellular concentration of $\mathrm{CO}_{2}$ in the winter wheat plants, treated with $\mathrm{Mo}$, in lines with contrast sensitivity to Mo compared to the variant without any treatment (Sun X, 2006). There are also some scientific data on the absence of positive effect of trace elements on photosynthetic indices. For instance, it was demonstrated that foliar treatment of barley plants with selenium affected the indices of photosynthetic apparatus activity or $\mathrm{CO}_{2}$ gas exchange neither in optimal nor in stressful conditions (Habibi G, 2013).

The impact of trace elements on photosynthetic pigments. The content of chlorophyll is one of the key traits of photosynthetic activity in leaves (Singh SK, 2017). A pigment complex is the basis for photosynthetic transformation of solar energy into the energy of chemical bonds. Chlorophyll molecules absorb photons of light and transmit the excitation energy to the photosynthetic reaction centers (Lichtenthaler HK, 1987; Bukhov NG et al, 1998; Golovko T and Tabalenkova G, 2014). Under deficiency of solar light, carotenoids are wellknown as light-harvesting pigments, and act to protect photosynthetic apparatus from the harmful effects of excess exposure to light (Sun T, 2018). Many articles have been presented on the research of the effect of some trace elements and their combined application on chlorophyll content. For instance, it was demonstrated that its content in corn leaves increased considerably 
compared against the control after simultaneous introduction of zinc into soil and foliar treatment of plants with $\mathrm{Zn}$ (Liu $\mathrm{H}$ et al, 2016). The chlorophyll content in corn leaves increased also after foliar treatment of plants with Mg compared against the control (Jezek M et al, 2015). Field experiments determined the 7-28\% increase in chlorophyll content in winter wheat leaves after double foliar treatment of plants with different doses of either magnesium and copper separately, or with their combinations compared against the control (El-Metwally AE, 2010). Spraying of plants with $\mathrm{Mg}$ in different phases of development also increased the chlorophyll content in soybean leaves (by 5-10 \%) but had insignificant effect on its content in corn (Altarugio LM, 2017). Foliar treatment of French bean plants with organic and inorganic salts of iron increased the content of the sum of chlorophylls $a$ and $b$ and carotenoids in leaves (Borowski E and Mihalek, S 2011). A considerable increase in the content of both chlorophyll forms and carotenoids was determined in winter wheat leaves in the sand culture after the introduction of either molybdenum or zinc into soil or their combined application (Liu C et al, 2019). Higher accumulation of chlorophyll and carotenoids in wheat leaves was determined under low temperature stress and treatment with Mo, compared against the control variant (Sun X, 2006; Yu M et al, 2006). Due to the effect of molybdenum, there was an increase in the number of chloroplasts in the cell, the volume of mitochondria and the amount of chlorophyll per chloroplast in sugar beet leaves (Kaiser $\mathrm{BN}$ et al, 2005). In some variants of the experiments with wheat plants on lime soils, the introduction into soil of or foliar spraying with $\mathrm{Fe}$ and $\mathrm{Zn}$ promoted a considerable (1.75-2-fold) increase in the content of total chlorophyll in the leaves on the $45^{\text {th }}$ and $70^{\text {th }}$ days of vegetation (Kandoliya RU et al, 2018).

The impact of trace elements on antioxidant enzymes. One of the ways to increase the efficiency of photosynthetic apparatus of plants both during the vegetation and under the effect of unfavorable factors is the optimization of the antioxidant protection systems (Gill SS and Tuteja N, 2010; Kolupaev YE, 2016; Vardhini BV and Anjum NA, 2015). The content and activity of antioxidant enzymes are relevant components of this protection, especially under stress conditions (Gill SS and Tuteja N, 2010; Alscher RG et al, 2002; Kolupayev $\mathrm{YuE}$ et al, 2019). The abovementioned is related to the fact that under stress the excessively absorbed light energy can result in the generation of toxic free radical forms of oxygen (Foyer CH and Noctor G, 2005; $\mathrm{Zhu} \mathrm{XG}$ et al, 2010). In addition, during the reproduc- tive period of development there is gradual aging of plant leaves and a decrease in the assimilation of $\mathrm{CO}_{2}$. Thus, there is a decrease in NADPH consumption during the Calvin cycle, which promotes the conditions for the superreduction of electron transport chain and the formation of reactive oxygen species (ROS) in chloroplasts which may damage the components of photosynthetic membranes and chloroplast stroma (Kiriziy DA et al, 2014; Munné-Bosch S et al, 2013). Usually, in response to the enhanced formation of ROS, there is the activation of the elements of antioxidant protection system of chloroplasts, the most relevant component of which is a system of antioxidant enzymes (Foyer CH and Noctor G, 2005; Asada K, 2006). During a series of consecutive reactions, they destroy superoxide radicals and hydrogen peroxide, which are formed in chloroplasts, thus ensuring the integrity of photosynthetic membranes and active functioning of the electron transport chain (Foyer CH and Shigeoka S, 2011).

According to the scientific data, the treatment of plants with trace elements promotes enhanced activity of antioxidant enzymes. For instance, foliar treatment of three chickpea cultivars with selenium increased the activity of superoxide dismutase (SOD, KF 1.15.1.1) and glutathione peroxidase (KF 1.11.1.9) but had no effect on the activity of catalase (CAT, KF 1.11.1.6) (Mohammadi A et al, 2011). A barley genotype, tolerant to the boron excess, had the increased activity of glutathione reductase (KF 1.8.1.7) under high content of boron in soil, while an efficient one demonstrated its decreased activity. The first genotype also had the increased SOD activity (Hamurcu M et al, 2017). It was demonstrated using sandy substrate that after the introduction of zinc into soil or its combined application with molybdenum there was a considerable increase in the activity of SOD, CAT and peroxidase (KF 1.11.7) in wheat leaves (Liu C et al, 2019). Under osmotic stress, simulated by polyethyleneglycol in the hydroponics culture, the variants with the application of Mo demonstrated a considerable increase in the activity of several antioxidant enzymes (SOD, peroxidase, CAT, ascorbate peroxidase (APO, KF 1.11.1.11)) in the winter wheat cultivar with a not high content of molybdenum, but when the Mo content was high, the difference from the control was significant only on some dates. Higher total and grain productivity of the latter cultivar allowed for the assumption that the application of Mo enhanced the ability to remove ROS (Wu SW, 2014). The mitigation of negative consequences, caused by drought, in 30-day-old wheat seedlings, grown on a solution that included Mo, may be related to the fact 
that nitrogen oxide ensures molybdenum-induced antioxidant protection, at least partially via the regulation of nitrate reductase (Wu S et al, 2017). It was also shown that $\mathrm{Zn}$ application enhanced the relative expression levels of two antioxidant enzyme genes, four ascorbate-glutathione cycle genes, and two flavonoid biosynthesis pathway genes under drought stress (Ma $\mathrm{D}$ et al, 2017). Thus, $\mathrm{Zn}$ fertilizer could regulate multiple antioxidant defense systems at the transcriptional level under drought.

A positive effect of separate trace elements and their combinations on the activity of antioxidant enzymes was also determined. For instance, under drought, the activity of SOD, CAT, and glutathione peroxidase after the introduction of 6 separate trace elements and their different combinations was higher in sunflower plants compared against control variant treatments without those trace elements (Rahimizadeh $\mathrm{M}$ et al, 2007). The most significant effect was observed in the variant, treated with a mixture of 4 trace elements $(\mathrm{Fe}, \mathrm{Zn}, \mathrm{Cu}$, $\mathrm{Mn})$ : the increase in the activity of these antioxidant enzymes was $48-89 \%$ compared with the control. Foliar treatment of corn plants with microfertilizers, including $\mathrm{Fe}, \mathrm{Zn}, \mathrm{Cu}, \mathrm{Mn}, \mathrm{B}, \mathrm{Mo}$ and $\mathrm{Mg}$, also promoted the increase in the activity of SOD, CAT, and glutathione peroxidase under drought (Sajedi NA et al, 2011). Therefore, the application of trace elements and their complexes in a number of cases promoted the intensification of protective reactions in the photosynthetic apparatus of the chloroplast.

The impact of trace elements on the traits of photosynthetic apparatus capacity. An important, yet less studied, aspect of the impact of trace elements is evaluating their application to the photosynthetic apparatus on different levels of the organization - from subcellular to cenosis. It is known that not all the effects, observed on lower levels of the organization of plants, are preserved on higher levels (Reynolds et al, 2001; Kiriziy DA et al, 2014)

The impact of trace elements on shoot dry weight is studied most frequently. Most of these studies have been conducted using seedlings and young plants. For instance, soaking corn seeds for different periods (from one minute to one hour) in $\mathrm{Zn}$ solution increased shoot dry weight by $4-32 \%$ in 22-day-old plants compared against the control (Torun B et al, 2017). Growing corn in the culture medium with zinc increased shoot dry weight of young plants twice (from 0.6 to $1.2 \mathrm{~g}$ ) and decreased the ratio between the roots and the aboveground part of plants (Hong W et al, 2017). Foliar appli- cation of iron to tomato plants, grown on hydroponics with high content of zinc, increased shoot and fruit dry weight for two investigated cultivars, although the increase was different (Kaya C et al, 1999).

The results of the study on the impact of trace elements on shoot dry weight of mature plants are more ambiguous. For instance, while treating with $\mathrm{Zn}$ there was a $20-51 \%$ increase in shoot dry weight in 65 winter wheat cultivars when plants were grown on lime soil (Cakmak I and Hoffland E, 2012). The data of twoyear field experiments with 10 wheat genotypes demonstrated the difference in the response of genotypes to the exogenous application of $\mathrm{ZnSO}_{4}$ (the introduction into soil with further foliar treatment of plants): for instance, zinc-sensitive genotype PBW 550 had a considerable (by $86 \%$ ) increase in the aboveground biomass (Bharti K et al, 2014). At the same time, no significant impact of foliar treatment with zinc was observed on the biomass of corn and wheat plants (Wang JW et al, 2012). The foliar treatment of barley plants with selenium promoted the increase in biomass by $14 \%$ under sufficient water supply, and under drought the differences were insignificant: shoot dry weight without and with the treatment using selenium was $1120 \pm 120$ and $1210 \pm 143 \mathrm{mg} /$ plant respectively (Habibi G, 2013). In two-year field experiments, the positive impact of soil fertilization using $\mathrm{Zn}(0,2.3,5.7,11.4,22.7,34.1 \mathrm{~kg}$ of $\mathrm{Zn}$ per ha) on the mass of straw and grain productivity of winter wheat was observed for two last introduced doses, whereas the introduction of $\mathrm{Zn}$ under $11.4 \mathrm{~kg} / \mathrm{ha}$ resulted in a significant increase in the shoot dry weight and root surface area in the $30 \mathrm{~cm}$ layer of soil while higher doses of $\mathrm{Zn}$ caused an insignificant decrease in these indices for the roots (Liu DY et al, 2019). The introduction of six norms of $\mathrm{Zn}$ in the field experiment increased the shoot biomass of corn plants especially in late phases of development: in the control about $200 \mathrm{~g} / \mathrm{plant}$, and in the treated ones 240-260 g/plant (Liu DY et al, 2020).

The results of the study on the impact of plant treatment using magnesium, iron and complexes of trace elements on the leaf area demonstrate the increase in the area of assimilation surface (Rawashdeh $\mathrm{H}$ and Sala F, 2014; Amirani DS and Kasraei P, 2015; Jung $S$ et al, 2017). A considerable difference was determined between treated and control plants in terms of leaf surface area of wheat cultivar Alex. Depending on the stage, when foliar treatment of plants using $\mathrm{Fe}$ was implemented, application of Fe $(1000 \mathrm{mg} / \mathrm{L})$ using iron chelate [Fe-DTPA, $6 \% \mathrm{Fe}$ ) on the stages of veg- 
etative growth may maximize the growth (compared with control, plant height increased from 9 to $12 \%$ ), and development of wheat (the number of plants, flag leaf area and flag leaf chlorophyll content were higher, $7-13 \%, 19-37 \%$ and $8-16 \%$ respectively, in comparison with the control) (Rawashdeh H and Sala F, 2014). Treating plants with a so-called MICROMAX mixture, including three trace elements $(\mathrm{B}, \mathrm{Zn}, \mathrm{Se})$, during the blossoming phase, resulted in a significant increase in the leaf index of mung bean (Vigna radiata L. Wilczek) under drought compared to the variant without any treatment (Amirani DS and Kasraei P, 2015). The results of the study on the impact of foliar treatment for four wheat cultivars using $\mathrm{Fe}$ also demonstrate a considerable increase in the leaf area index from 3.7$4.2 \mathrm{~m}^{2} / \mathrm{m}$ to $4.3-5.1 \mathrm{~m}^{2} / \mathrm{m}^{2}$, and it is noteworthy that the positive effect was the highest for Rijav cultivar (increased from 4.2 to $5.1 \mathrm{~m}^{2} / \mathrm{m}^{2}$ ) and the lowest - for Rashid cultivar (increased from 3.7 to $4.3 \mathrm{~m} / \mathrm{m}^{2}$ ) (Kahrariyan $\mathrm{B}$ et al, 2013).

\section{The influence of nanoparticles on photosynthetic} traits. Many countries are now abandoning the increased use of nitrogen to reduce both the cost of grain production and negative environmental consequences, as excessive amounts of nitrogen in the soil cause its acidification and significantly pollute water resources (Zhang F and Chen J, 2017) The need to reduce the technogenic load on the environment, on the one hand, and the development of nanotechnologies, on the other, highlight the urgency of studies on the specificities of the impact of nanoconcentrations of trace elements on physiological processes in general and photosynthesis in particular.

Some countries used nanotechnologies to elaborate a new generation of fertilizers with new properties and low doses of trace elements. The small size of nanoparticles, the neutrality of their charge, which help facilitate their penetration through cell walls, membranes, etc., determine a high level of their biological activity (Rameshaiah GN and Jpallavi S, 2015; Morales-Días A et al, 2017). In addition, they have fundamentally different qualities, since their mechanisms of action obey the laws of quantum mechanics (Mitin et al, 2010). The concentration of some metals (according to their content) in nanofertilizers can range from hundredths to thousands of percent (Kosinov MV and Kaplunenko VG, 2009; Raliya R et al, 2015). At the same time, the understanding of the interaction between nanoparticles and plants, including absorption, mobilization, and accumulation, is still in its infancy (Sanzari I et al, 2019).
The content of pigments and traits of photochemical activity of photosynthetic apparatus activity have recently become more frequent objects of studies. Some articles mention the positive impact of nanometals and nanocomplexes on the pigment indices. For instance, plants treated with aerosol-foliar applied $\mathrm{TiO}_{2}$ nanoparticles (size $25 \pm 3.5 \mathrm{~nm}$ ) in a range of concentrations from 10 to $1000 \mathrm{mg} / \mathrm{kg}$ showed chlorophyll content increasing in the leaves of 28-day-old tomato from 63 to $227 \%$ (Raliya $\mathrm{R}$ et al, 2015). The chlorophyll content index, measured using a chlorophyll measuring apparatus, on the second fully expanded leaf of seedlings of maize grown from the seeds which were washed with $2 \mathrm{~g} / \mathrm{L}$ ferrihydrite, is $18 \%$ higher compared with the control (Pariona $\mathrm{N}$ et al, 2017). In our own research, we have determined the impact of weather conditions on the efficiency of treating the plants with the complex of carboxylates of seven trace elements $(\mathrm{Mg}, \mathrm{Fe}, \mathrm{Cu}$, $\mathrm{Zn}, \mathrm{Mn}, \mathrm{Mo}, \mathrm{Co}$ ) on photosynthetic pigments content (Kapitanska OS et al, 2018). This complex of carboxylates of biometal-microelements is obtained by means of erosion-explosive technology with the subsequent chelation of nanoparticles of metals by natural carboxylic acids. For instance, during a cool and damp period of spring-summer vegetation, the content of chlorophylls in the leaves of three winter wheat cultivars increased less during some phases (by 4-8\%) than under drought (by 13-19\%) compared to the relevant controls. The content of carotenoids increased by $7 \%$ and $14-15 \%$ respectively. Thus, the impact of treating the plants with the complex of trace elements on the photosynthetic pigments content under drought was higher. No significant impact of the treatments on the ratio of chlorophyll forms was determined.

The positive effect of using zinc and copper nanochelates under stressful conditions on chlorophyll content was determined and variety-specificity of their action was revealed (Taran $\mathrm{N}$ et al, 2017). It was demonstrated that under conditions of sufficient water supply, the chlorophyll content in the leaves of winter wheat seedlings of the variety Stolichna, (less productive variety, forrest-steppe ecotype), which grew in the variants with the addition of zinc and copper nanochelates to the nutrient solution, was increasing whereas the difference for variety Acveduc (more productive variety, steppe ecotype) was insignificant compared to the variant without any treatment (Taran $\mathrm{N}$ et al, 2017). However, chlorophyll content was less in both cultivars under drought: in the treated variant its content decreased by $18-22 \%$, whereas in the control by $29-45 \%$. Thus, the efficiency of applying these nanochelates was higher 
under unfavorable conditions. Seed treatment with zinc and copper nanoparticles caused the decrease of this ratio by $12 \%$ in leaves of the Stolichna variety seedlings and an increase of $37 \%$ in leaves of the Acveduc variety seedlings. Drought, on the contrary, induced the increase of chlorophyll $\mathrm{a} / \mathrm{b}$ ratio by $32 \%$ in leaves of the first variety and the decrease of it by $12 \%$ in the second one (Taran $\mathrm{N}$ et al, 2017). However, there is evidence of a negative impact of some nanoparticles on the content of photosynthetic pigments. For instance, the application of silver nanoparticles demonstrated the opposite effect: there was degradation of chlorophyll b when $60 \mathrm{mg} / \mathrm{L} \mathrm{Ag-nanoparticles} \mathrm{were} \mathrm{applied} \mathrm{to} \mathrm{rice}$ plants (Mirzajani F et al, 2013).

The indirect effect of inoculation with the nodule bacterium Bradyrhizobium japonicum, cultivated in the medium with chelated nanoparticles of $\mathrm{Mo}, \mathrm{Ge}$, and $\mathrm{Fe}$, was determined on the rate of soybean photosynthesis: at three true leaves it was $22-35 \%$ higher compared against the control, except for the variant with $\mathrm{Fe}$, at budding $-20-58 \%$ higher in all the experiment variants (Morgun VV et al, 2019). The application of carboxylates of these metals in the composition of inocula activated the processes of $\mathrm{CO}_{2}$ assimilation of soybean regardless of the strain of nodule bacteria. The fact that all the studied strains of nodule bacteria increased the $\mathrm{CO}_{2}$ assimilation is explained by the fact that the stimulation of nitrogen-fixing activity by nanometal increased the supply of nitrogen-containing compounds from the roots. And this, in turn, causes an increase in the gas exchange of carbon dioxide.

The positive effect of treating plants with specific nanoparticles on the traits of photosynthetic apparatus activity (quantum efficiency of photosystem II, photochemical and non-photochemical quenching electron transport rate) was determined. For instance, the impact of the foliar treatment of sunflower plants with normal and nanosize zinc oxide $(\mathrm{ZnO})$ under saline stress and without a stress factor on chlorophyll fluorescence parameters demonstrated an increase in the maximal quantum yield of PS II ( $\mathrm{Fv} / \mathrm{Fm})$ while applying the nanosize zinc oxide $(\mathrm{ZnO})$ to five cultivars of sunflower (Torabian $\mathrm{S}$ et al, 2016). The research of the impact of nano-silicon on chlorophyll fluorescence parameters (maximal and true quantum efficiency of PS II, photochemical and non-photochemical quenching coefficients, and electron transport rate) in the leaves of wheat plants, grown on the nutrient solution without and with silicon, demonstrated a significant difference between control and experimental plants
48-120 h after the treatment (Perez CE et al, 2014). So, maximum and true quantum quenching of PS II were higher, than that of the control, respectively by $1-5$ and $10-22 \%$ (Perez CE et al, 2014). Our research with two winter wheat varieties (Astarta and Natalka), grown in pots with $10 \mathrm{~kg}$ of fertilized soil at natural light, demonstrated that the foliar treatment plants with a mixture of seven trace elements, produced using nanotechnological methods, enhanced the resistance of photosynthetic apparatus to soil drought (Stasik OO et al, 2020). The decrease in photosynthetic activity of flag leaves in plants treated with the microelement complex was less (36 and $33 \%$ in varieties Astarta and Natalka, respectively) compared to untreated plants (46 and $52 \%$ ). Under moisture deficiency, the photosynthetic rate in treated plants was higher than in ones without treatment: by $22 \%$ for Astarta and $34 \%$ for Natalka. The decrease in the PS II maximum quantum efficiency was about $2 \%$ in the treated plants of both varieties, while in the control plants of Astarta and Natalka varieties -5 and $12 \%$, respectively. Under drought the PS II true quantum efficiency of variety Natalka in the treated plants was higher than untreated plants by $35 \%$. The maintenance of higher net $\mathrm{CO}_{2}$ assimilation rate and photochemical activity of PS II under drought was accompanied with the increase in grain productivity of variety Natalka plants (by $18 \%$ ) (Stasik OO et al, 2020). We have also determined that the treatment of plants with the same complex increased the activity of SOD and APX (by 9-60\% depending on the phase of development and variety) in the chloroplasts of flag leaves during the period of kernel ripening (Sokolovska-Sergiienko OG et al, 2017). At the same time, some studies have demonstrated that nanofertilizers had the same effectiveness or were even less effective than conventional fertilizers: for example, absorption by leaf wheat of chelated $\mathrm{Zn}$ (ZnEDTA) was greater than $\mathrm{Zn}$ oxide nanoparticles (Kopittke PM et al, 2019; Read et al, 2019).

There are still scarce studies on the mechanisms of the effect of small amounts of trace elements on the plant metabolism. Some researchers such as Kobayashi M, Verbruggen N and Hermans C, Bityutskyy V, Ma D believe that nanometals may be involved in the activation of regulatory mechanisms. The assumption about the activation of regulatory mechanisms at the effect of low doses of trace elements may be confirmed by the results of the study, conducted by Kobayashi et al (Kobayashi $\mathrm{M}$ et al, 2004). As boron deficiency affected the 


\section{PRIADKINA}

level of tobacco gene expression, related to the oxidative stress, the authors assumed that boron may act as a signaling molecule and play a regulatory role due a faster signal transmission from the cellular wall to cytoplasm, which may be involved in the induction of genes (Verbruggen N Hermans C, 2013). This hypothesis may be favored by the data about considerable differences in the expression of Arabidopsis genes, related to circadian rhythms, the synthesis of ethylene, photoprotective systems of the photosynthetic apparatus, and the processes of chlorophyll catabolism in the control and under magnesium deficiency (Bityutskyy V et al, 2017). Thus, the effect of magnesium may be related to the activation of several regulatory mechanisms. In addition, the increase in the relative level of expression of two antioxidant enzyme genes (for SOD and peroxidase), four genes of ascorbate-glutathione cycle and two genes, controlling the synthesis of flavonoids in wheat plants, treated with zinc, was determined under drought compared against the control (Ma D et al, 2017). So, under drought the treatment of plants with zinc may affect the regulation of several antioxidant systems of protection on the level of transcription. Another mechanism of action for trace elements may be their function as a source of sustained release, conditioned by the improvement in the effectiveness of using nutrients (Kopittke PM et al, 2019; Morgun VV et al, 2019).

Trace elements applied in the form of nanoparticles have many advantages compared to their analogues applied in a usual form. Ultrasmall sizes of nanoparticles promote better bioavailability, the ability to overcome biological barriers and to better form chemical bonds with nucleic acids and proteins, integrating into cellular membranes, penetrating organellas and changing their functions (Bityutskyy et al, 2017; Ivanov VK et al, 2013). In the form of neutral non-soluble combinations of elements or reduced metals with zero valency they do not require the services of ion transfer mechanism and, due to their small sizes, may penetrate plant cells faster. For instance, a higher rate of their absorption compared against common trace elements has been demonstrated using animal objects. The serum level of female rats 24 hours after injection of selenium in nano treated group was significantly higher than that of the bulk selenium group, respectively, 60.01 and $32.67 \mathrm{ppm}$ (Pouri E et al, 2017). In addition, trace elements in their nanoform are close to biometalorganic compounds, synthesized in plant cells, by their biochemical structure and chemical purity. This is likely to ensure their high biocompatibility and thus high availability. Thus, the improvement of photosynthetic characteristics, caused by the applica- tion of nanopreparations, will have high biological effectiveness under smaller doses of application compared against common trace elements. At the same time, there is a problem of toxicity or danger of using nanoparticles (Chichiriccó G and Poma A, 2015; Dykman LA and Shchyogolev SY, 2017), but we do not discuss these problems in this review.

Taking into consideration the fact that the improvement of photosynthesis efficiency is currently viewed as a key strategy of increasing the yield of crops, the optimization of photosynthetic processes via the application of trace elements may be a vital factor, affecting the course of yield formation. The analysis of the scientific data and the results of our investigations (Priadkina GO et al, 2014; Kapitanska OS et al, 2016; Sokolovska-Sergiienko OG et al, 2017; Kapitanska OS et al, 2018; Stasik OO et al, 2020) demonstrates that trace elements promote the optimization of working efficiency of the photosynthetic apparatus of plants due to the increase in the rate of $\mathrm{CO}_{2}$ gas exchange, the content of photosynthetic pigments, enzymatic activity, leaf area index of crops and aboveground biomass. Thus, the effect of trace elements is manifested both on lower and more complex levels of organizing the photosynthetic apparatus. A positive effect of using trace elements is related to their direct and indirect involvement in photosynthetic processes and in the activation of different regulatory mechanisms. The genotypic difference in the response of photosynthetic parameters to the impact of specific trace elements (Bharti $\mathrm{K}$ et al, 2014; Hamurcu M et al, 2017; Kahrariyan B et al, 2013; Taran N et al, 2017; Schmidt SB et al, 2019; Wu SW, 2014) may be used to breed highly productive plants. As the treatment of plants with trace elements enhances the resistance of the photosynthetic apparatus to the effect of stress factors, including drought, salinization, low temperatures, etc., their application may promote the improvement of plant productivity under the mentioned conditions (Sajedi NA et al, 2011; Zang M, 2012; Wu SW, 2014; Torabian S et al, 2016; Ma D et al, 2017; Stasik OO et al, 2020). The maintenance of efficient work of photosynthetic apparatus on the background of increasing air temperature, more frequent droughts, and heavy precipitations along with the enlarged geographical ranges and activity of pests, and spreading of diseases, is getting special significance in modern conditions.

The results of numerous studies demonstrate that trace elements affect the metabolic processes, starting with the molecular level (controlling the expression 
level of some genes, photochemical activity of photosystems) and ending with the cenotic level (leaf area index of the crop and productivity) (Table).
Given that enhancement of the photosynthetic efficiency is now seen as a key strategy to increase crop yields (Parry MAJ et al, 2011; Long SP et al, 2015),

The impact of trace elements and their mixtures in a common and/or nano- form (under different stress/non-stress conditions) on the photosynthetic parameters and indices of the production process for different agricultural plants

\begin{tabular}{|c|c|c|c|c|}
\hline Index & $\begin{array}{l}\text { Trace element/ } \\
\text { mixture }\end{array}$ & Culture & Stress factor & Source \\
\hline $\begin{array}{l}\text { Maximum quantum } \\
\text { efficiency of photosystem } \\
\text { II (PS II) }\end{array}$ & $\begin{array}{l}\mathrm{Se} \\
\mathrm{Zn}\end{array}$ & $\begin{array}{l}\text { Wheat } \\
\text { Sunflower }\end{array}$ & $\stackrel{-}{\text { Salinization }}$ & $\begin{array}{l}\text { Perez CE et al, } 2014 \\
\text { Torabian S et al, } 2016\end{array}$ \\
\hline $\begin{array}{l}\text { Rate of photosynthesis, PS } \\
\text { II maximum and true quan- } \\
\text { tum efficiency }\end{array}$ & $\begin{array}{l}\mathrm{Mg}+\mathrm{Fe}+\mathrm{Cu}+\mathrm{Zn}+ \\
+\mathrm{Mn}+\mathrm{Mo}+\mathrm{Co}\end{array}$ & Wheat & Drought & Stasik OO et al, 2020 \\
\hline Rate of photosynthesis & $\begin{array}{l}\mathrm{Fe} \\
\mathrm{Mo} \\
\mathrm{Mo} \\
\mathrm{Mo} \\
\mathrm{Zn} \\
\mathrm{Zn} \\
\text { Mo, Zn, Mo + Zn } \\
\text { Mo, Ge, Fe }\end{array}$ & $\begin{array}{l}\text { French beans } \\
\text { Wheat } \\
\text { Wheat } \\
\text { Chinese cabbage } \\
\text { Wheat } \\
\text { Corn } \\
\text { Wheat } \\
\text { Soybean }\end{array}$ & $\begin{array}{l}\quad- \\
- \\
\text { Low temperature } \\
\text { Saline stress } \\
- \\
- \\
\text { Depleted substrate } \\
-\end{array}$ & $\begin{array}{l}\text { Borowski E Mihalek S, } 2011 \\
\text { Wu SW, } 2014 \\
\text { Sun X, } 2006 \\
\text { Zang M, } 2012 \\
\text { Bharti K et al, } 2014 \\
\text { Liu H et al, } 2016 \\
\text { Liu C et al, } 2019 \\
\text { Morgun VV et al, } 2019\end{array}$ \\
\hline $\begin{array}{l}\text { Transpiration rate, stomatal } \\
\text { conductance, intercellular } \\
\mathrm{CO}_{2} \text { concentration }\end{array}$ & Mo & French beans & - & $\begin{array}{l}\text { Borowski E Mihalek S, } \\
2011\end{array}$ \\
\hline $\begin{array}{l}\text { Stomatal conductance, } \\
\text { transpiration rate }\end{array}$ & Mo & Wheat & Low temperatures & Sun X, 2006 \\
\hline $\begin{array}{l}\text { Transpiration rate } \\
\text { Content of chlorophylls } a \\
\text { and } b\end{array}$ & $\begin{array}{l}\mathrm{Zn} \\
\mathrm{Mg} \\
\mathrm{Zn} \\
\mathrm{Fe}, \mathrm{Zn} \\
\mathrm{Mg}, \mathrm{Cu} \\
\mathrm{Fe} \\
\mathrm{Ti} \\
\mathrm{Cu}+\mathrm{Zn} \\
\mathrm{Mg}+\mathrm{Fe}+\mathrm{Cu}+\mathrm{Zn}+ \\
+\mathrm{Mn}+\mathrm{Mo}+\mathrm{Co}\end{array}$ & $\begin{array}{l}\text { Corn } \\
\text { Corn } \\
\text { Corn } \\
\text { Wheat } \\
\text { Wheat } \\
\text { Corn } \\
\text { Tomato } \\
\text { Wheat } \\
\text { Wheat }\end{array}$ & \begin{tabular}{|r}
- \\
- \\
- \\
- \\
- \\
- \\
- \\
Drought \\
Drought
\end{tabular} & $\begin{array}{l}\text { Liu H et al, } 2016 \\
\text { Jezek M et al, } 2014 \\
\text { Liu H et al, } 2016 \\
\text { Kandoliya RU et al, } 2018 \\
\text { El-Metwally AE, } 2010 \\
\text { Pariona N et al, } 2017 \\
\text { Raliya R et al, } 2015 \\
\text { Taran N et al, 2017 } \\
\text { Kapitanska OS et al, } 2018\end{array}$ \\
\hline $\begin{array}{l}\text { Content of chlorophylls } \\
a \text { and } b \text {, as well as total } \\
\text { carotenoids }\end{array}$ & $\begin{array}{l}\text { Mo } \\
\text { Mo, Zn, Mo }+\mathrm{Zn} \\
\text { Mo, Zn, Mo }+\mathrm{Zn} \\
\text { Se }\end{array}$ & $\begin{array}{l}\text { French beans } \\
\text { Wheat } \\
\text { Wheat } \\
\text { Chickpea }\end{array}$ & $\begin{array}{c}- \\
\text { Low temperatures } \\
\text { Depleted substrate } \\
-\end{array}$ & $\begin{array}{l}\text { Borowski E Mihalek S, } 2011 \\
\text { Sun X, 2006; Yu M et al, } 2006 \\
\text { Liu C et al, } 2019 \\
\text { Mohammadi A et al, } 2011\end{array}$ \\
\hline $\begin{array}{l}\text { Activity of ascorbate peroxi- } \\
\text { dase, catalase, and peroxidase }\end{array}$ & Mo & Wheat & Osmotic stress & Wu SW, 2014 \\
\hline Activity of nitrate reductase & Mo & Wheat & Drought & Wu S et al, 2017 \\
\hline $\begin{array}{l}\text { Activity of superoxide dismu- } \\
\text { tase, catalase, and peroxidase }\end{array}$ & $\mathrm{Mo}, \mathrm{Zn}, \mathrm{Mo}+\mathrm{Zn}$ & Wheat & Depleted substrate & Liu C et al, 2019 \\
\hline $\begin{array}{l}\text { Activity of superoxide dismu- } \\
\text { tase, catalase, and glutathione } \\
\text { oxidase }\end{array}$ & $\begin{array}{l}\mathrm{Fe}+\mathrm{Zn}+\mathrm{Cu}+\mathrm{Mn}+ \\
\mathrm{B}+\mathrm{Mo}+\mathrm{Mg} \\
\mathrm{Fe}+\mathrm{Zn}+\mathrm{Cu}+\mathrm{Mn}\end{array}$ & $\begin{array}{l}\text { Corn } \\
\text { Sunflower }\end{array}$ & $\begin{array}{l}\text { Drought } \\
\text { Drought }\end{array}$ & $\begin{array}{l}\text { Sajedi NA et al, } 2011 \\
\text { Rahimizadeh M et al, } 2007\end{array}$ \\
\hline $\begin{array}{l}\text { Activity of superoxide dismu- } \\
\text { tase and ascorbate peroxidase }\end{array}$ & $\begin{array}{l}\mathrm{Mg}+\mathrm{Fe}+\mathrm{Cu}+\mathrm{Zn}+ \\
\mathrm{Mn}+\mathrm{Mo}+\mathrm{Co}\end{array}$ & Wheat & - & $\begin{array}{l}\text { Sokolovska-Sergiienko OG } \\
\text { et al, } 2014\end{array}$ \\
\hline
\end{tabular}


PRIADKINA

End of table

\begin{tabular}{|c|c|c|c|c|}
\hline Index & $\begin{array}{l}\text { Trace element/ } \\
\text { mixture }\end{array}$ & Culture & Stress factor & Source \\
\hline $\begin{array}{l}\text { Activity of superoxide dismu- } \\
\text { tase and peroxidase, genes } \\
\text { expression level }\end{array}$ & $\mathrm{Mg}$ & Wheat & Drought & Ma D et al, 2017 \\
\hline Shoot dry weight & $\begin{array}{l}\mathrm{Zn} \\
\mathrm{Zn}\end{array}$ & $\begin{array}{l}\text { Corn } \\
\text { Wheat }\end{array}$ & Lime soil & $\begin{array}{l}\text { Torun B et al, } 2017 \\
\text { Hong W et al, } 2017 \\
\text { Cakmak I and Hoffland E, } \\
2012\end{array}$ \\
\hline Shoot and fruit dry weight & $\mathrm{Fe}$ & Tomato & $\begin{array}{l}\text { High } \mathrm{Zn} \text { content in } \\
\text { the substrate }\end{array}$ & Kaya C et al, 1999 \\
\hline Aboveground biomass & $\begin{array}{l}\mathrm{Se} \\
\mathrm{Zn} \\
\mathrm{Zn}\end{array}$ & $\begin{array}{l}\text { Barley } \\
\text { Wheat } \\
\text { Corn }\end{array}$ & $\begin{array}{l}- \\
- \\
-\end{array}$ & $\begin{array}{l}\text { Habibi G, } 2013 \\
\text { Bharti K et al, } 2014 \\
\text { Liu DY et al, } 2020\end{array}$ \\
\hline $\begin{array}{l}\text { Weight of straw and roots } \\
\text { Area of leaves } \\
\text { Canopy leaf area index }\end{array}$ & $\begin{array}{l}\mathrm{Zn} \\
\mathrm{Fe} \\
\mathrm{Fe} \\
\mathrm{Mg} \\
\mathrm{B}, \mathrm{Zn}, \mathrm{Se}\end{array}$ & $\begin{array}{l}\text { Wheat } \\
\text { Wheat } \\
\text { Wheat } \\
\text { Corn } \\
\text { Mung bean }\end{array}$ & $\begin{array}{l}- \\
-\end{array}$ & $\begin{array}{l}\text { Liu DY et al, } 2019 \\
\text { Rawashdeh H, Sala F, } 2014 \\
\text { Kahrariyan B et al, } 2013 \\
\text { Jung S et al, } 2017 \\
\text { Amirani DS and Kasraei P, } \\
2015\end{array}$ \\
\hline
\end{tabular}

Note. - - No impact of stress factors.

optimizing photosynthetic processes through the use of trace elements can be an important factor for improving crop yields. In addition, trace elements impact the systems of plant protection from the oxidative stress via the enhanced activity of antioxidant enzymes. It is becoming especially relevant in current conditions of climatic changes. Thus, the fertilization of plants using trace elements should become an integral part of modern technologies of cultivating different agricultural crops. The development of nanotechnologies and the elaboration of preparations with new properties and low concentrations of trace elements may also serve as the basis for the development of next-generation bioecologic technologies. However, a wide application of nanomaterials in agriculture requires thorough preliminary analysis of their safety for man, animals and the environment and economic efficiency. The elaboration of new phytonanotechnologies would be facilitated by the combined efforts of plant physiologists, geneticists, and agronomists.

The article contains, apart from the data obtained from the study of the relevant literature also the results of our own research investigations of the project "Physiological foundations of enhancing productivity and resistance of agricultural plants under global climatic changes", conducted within the framework of a target program of scientific studies of the Department of gen- eral biology, NAS of Ukraine, "Fundamental foundations of forecasting and preventing the negative effect of climatic changes on the biotic systems of Ukraine" (program budget classification code 6541030).

Вплив мікроелементів у класичній та наноформі на фотосинтез вищих рослин у зв'язку з підвищенням продуктивності

\section{Г. О. Прядкіна}

Інститут фізіології рослин і генетики Національної академії наук України, вул. Васильківська, 31/17 Київ, 03022

E-mail: galpryadk@gmail.com

Одним з основних чинників збільшення врожайності сільськогосподарських рослин є підвищення активності фотосинтетичного апарату, оскільки продуктивність посівів пов'язана із здатністю поглинання сонячної радіації і її перетворення в енергію хімічних зв'язків для подальшого використання в метаболічних процесах. Кількість поглиненої посівами фотосинтетично активної радіації, в свою чергу, залежить від площі, тривалості та активності функціонування асиміляційної поверхні. В сучасних умовах підвищення врожайності культурних рослин і одночасне зниження техногенного навантаження пов' язують із застосуванням мікродобрив. У зв'язку з цим, в огляді обговорено сучасний стан досліджень впливу основних мікроелементів і магнію на фотосинтетичні характеристики рослин і посівів. На 
базі літературних даних та результатів власних досліджень проаналізовано вплив мікроелементів на показники газообміну $\mathrm{CO}_{2}$, вміст фотосинтетичних пігментів та активність антиоксидантних ферментів в листках, а також показники потужності розвитку фотосинтетичного апарату. Розглянуто особливості дії нанометалів на вміст та співвідношення пігментів, інтенсивність асиміляції $\mathrm{CO}_{2}$ та показники фотохімічної активності фотосистем. Враховуючи розвиток нанотехнологій, обговорено особливості дії нанометалів та проаналізовано можливі механізми впливу низьких концентрацій мікроелементів на рослинний метаболізм. Обгрунтовано ефективність застосування мікроелементів за дії стресових чинників, висвітлено їх значення для розвитку нових стратегій розробки біоекологічних технологій наступного покоління.

Ключові слова: нанометали, фотосинтетичні пігменти, антиоксидантні ферменти, асиміляція $\mathrm{CO}_{2}$.

\section{REFERENCES}

Alscher RG, Erturk N, Heath LS (2002) Role of superoxide dismutases (SODs) in controlling oxidative stress in plants. J Exp Bot. 53(372):1331-1341. doi: 10.1093/jexbot/ 53.372.1331.

Altarugio LM, Loman MH, Nirschl MG et al (2017) Yield performance of soybean and corn subjected to magnesium foliar spray. Pesq Agropec Braz. 52(12):1185-1191. doi: 10.1590/s0100-204x2017001200007.

Amirani DS, Kasraei P (2015) The effect of foliar application of microelements on phenological and physiological characteristics of Mung bean under drought stress. IJAAR. 7(3):1-8.

Andresen E, Peiter E, Küpper $H$ (2018) Trace metal metabolism in plants. J Exp Bot. 69(5):909-954. doi: 10.1093/ $\mathrm{jxb} / \mathrm{erx} 465$.

Asada K (2006) Production and scavenging of reactive oxygen species in chloroplasts and their functions. Plant Physiol. 141(2):391-396. doi: 10.1104/pp.106.082040.

Beadle CL, Long SP (1985) Photosynthesis: is it limiting to biomass production? Biomass. 8:119-168. doi: 10.1016/ 0144-4565(85)90022-8.

Bharti K, Pandey N, Shankhdhar D et al (2014) Effect of exogenous zinc supply on photosynthetic rate, chlorophyll content and some growth parameters in different wheat genotypes. Cereal Res Commun. 42(4):589-600. doi: 10.1556/CRC.2014.0015.

Biswas DK, Xu H, Li YJ (2008) Genotypic difference in leaf biochemical, physiological and grown responses to ozon in 20 winter wheat cultivars over the past 60 years. Glob Chang Biol. 14(1):46-59. doi: 10.1111/j1365-2486. 2007.01477.x.

Bityutskyy V, Tsekhmistrenko O, Tsekhmistrenko Set al (2017) Perspectives of cerium nanoparticles use in agriculture. Anim Biol. 19. 9-17. 10.15407/animbiol19.03.009.

Borowski E, Mihalek S(2011) The effect of foliar fertilization of french bean with iron salts and urea on some physiological processes in plants relative to iron uptake and translocation in leaves. Acta Sci Pol Hortorium 10(2):183-193.

Brisson N, Gate Ph, Gouache D et al (2010) Why are wheat yields stagnating in Europe? A comprehensive data analysis for France. Field Crop Res. 119(1):201-212. doi: 10.106/j.fcr.2010.07.012.

Bukhov NG, Bondar VV, Drozdova IS (1998) Effects of blue and red light of low intensity on chlorophyll a and $\mathrm{b}$ contents in barley leaves and light curves of photosynthesis. Rus J Plant Physl. 45(4):428-432.

Cakmak I, Hoffland E (2012) Zinc for the improvement of crop production and human health. Plant and Soil. 361(1-2):1-2. doi: 10.1007/s11104-012-1504-0.

Cakmak I and Marschner H (1992). Magnesium deficiency and high light intensity enhance activities of superoxide dismutase, ascorbate peroxidase and glutathione reductase in bean leaves. Plant Physiol. 98(4):1222-1227. doi: 10.1104/pp.98.4.1222.

Chichiriccó G, Poma A (2015) Penetration and toxicity of nanomaterials in higher plants. Nanomaterials. 5:851873. doi: 10.3390/nano5020851.

Dermody O, Long SP, McConnaughay K et al (2008) How do elevated $\mathrm{CO}_{2}$ and $\mathrm{O}_{3}$ affect the interception and utilization of radiation by a soybean canopy? Glob Chang Biol. 14 (3):556-564. doi: 10.1111/j1365-2486.2007.01502.x.

Dimkpa CO, Bindraban PS (2016) Fortification of micronutrients for efficient agronomic production: a review. Agron Sustain Dev. 36(1):7. doi: 10.1007/s13593-0150346-6.

dos Santos EF, Zanchim BJ, de Campos AG et al (2013) Photosynthesis rate, chlorophyll content and initial development of physic nut without micronutrient fertilization. R Bras Si Solo. 37(5):1334-1342. doi: 10.1590/ S0100-06832013000500022.

Dykman LA, Shchyogolev SY (2017) Interactions of plants with noble metal nanoparticles (review). Agric Biol. 52(1):13-24. doi: 10.15389/agrobiology.2017.1.13eng.

El-Metwally AE, Abdalla FE, El-Saadi AM et al (2010) Response of Wheat to Magnesium and Copper Foliar Feeding under Sandy Soil Condition. J Amer Sci. 6(12):818-823. doi: 10.7537/marsjas061210.91.

Evans LT, Wardlaw IF, Fisher RA (1975) Wheat. In: Evans LT (ed) Crop Physiology, Cambridge University Press, London, p. 101-149.

Foyer CH, Noctor G (2005) Redox homeostasis and antioxidant signaling: a metabolic interface between stress perception and physiological responses. Plant Cell. 17(7):1866-1875. doi: 10.1105/tpc.105.033589.

Foyer CH, Shigeoka S (2011) Understanding oxidative stress and antioxidant functions to enhance photosynthesis. Plant Physiol. 155(1):93-100. doi: 10.1104/pp.110.166181.

Gill SS, Tuteja $N$ (2010) Reactive oxygen species and antioxidant machinery in abiotic stress tolerance in crop 


\section{PRIADKINA}

plants. Plant Physiol Biochem. 48(12):909-930. doi: 10.1016/j.plaphy.2010.08.016.

Golovko T, Tabalenkova G (2014) Pigments and productivity of the crop plants. In: Golovko TK, Gruszecki W.I., Prasad MNV, Strzbalka (eds) Photosynthetic pigments: chemical structure, biological function and ecology, Syktyvkar, p 207-220.

Goudia BD and Hash CT (2015). Breeding for high grain Fe and $\mathrm{Zn}$ levels in cereals. IJIAS, 12(2):342-354.

Habibi G (2013) Effect of drought stress and selenium spraying on photosynthesis and antioxidant activity of spring barley. Acta Agric Slov. 101(1):31-39. doi: 10. 2478/acas-2013-0004.

Hamurcu M, Hakki EE, Onbaşi S et al (2017) Exogenous nitric oxide alleviates boron toxicity effects on two Turkish barley genotypes. In: XVIII International Plant Nutrition Colloquium, Copenhagen, Denmark, 19-24 Aug 2017.

Hong W, Jinyao Z, Daoping $W$ et al (2017) Proteomic responses to zinc deficiency stress in maize (Zea mays. L) In: XVIII International Plant Nutrition Colloquium, Copenhagen, Denmark, 19-24 Aug 2017.

Hubbart S, Smillie IRA, Heatley M et al (2018) Enhanced thylakoid photoprotection can increase yield and canopy radiation use efficiency in rice. Commun Biol 1(22). doi: 10.1038/s42003-018-0026-6.

Husted S, Schmidt SB, Hansen TH et al (2017) Bioimaging and molecular speciation analysis of essential plant nutrients. In: XVIII International Plant Nutrition Colloquium, Copenhagen, Denmark, 19-24 Aug 2017. https:// data.worldbank.org/indicator/AG.LND.ARBL.ZS.

Ivanov VK, Shcherbakov AB, Baranchykov AE et al (2013) Nanokristallicheskiy dioksid tseriya: svoystva, polucheniye, primeneniye. [Nanocrystallized cerium dioxide: properties, receipt, and application]. Tomsk University Press, Tomsk.

Jezek M, Geilfus Ch-M, Mühling K (2015) Glutamine synthetase activity in leaves of Zea mays L. as influenced by magnesium status. Planta. 242(6):1309-1319. doi: 10.1007/s00425-015-2371-8.

Jiang GM, Sun JZ, Lui QN et al (2003) Changes in rate of photosynthesis accompanying the yield increase in wheat cultivars released in the past 50 years. J Plant Res. 16(5):347-354. doi: 10.1007/s10265-003-0115-5.

Jung S, Faust FE, Schubert $S$ (2017) Limiting physiological processes for maize growth under $\mathrm{Mg}$ deficiency. In: XVIII International Plant Nutrition Colloquium, Copenhagen, Denmark, 19-24 Aug 2017.

Kabata-Pendias A (2011) Trace elements in soils and plants. 4th ed. Boca Raton FL: CRC Press. doi: 10.1201/b10158.

Kahrariyan B, Yeganehpoor F, Beyginiya V et al (2013) Effect of $\mathrm{Fe}$ foliar application on morphological and physiological traits of different dryland wheat cultivars. IJABBR. 1(12):1583-1589.

Kaiser BN, Gridley KL, Ngaire Brady J et al (2005) The role of molybdenum in agricultural plant production. Annals Bot. 96(5):745-754. doi: 10.1093/aob/mci226.
Kandoliya RU, Sacarvadiya HL, Kunjadia BB (2018) Effect of zinc and iron application on leaf chlorophyll, carotenoid, grain yield and quality of wheat in calcareous soil of Saurashtra region. Int J Chem Studies. 6(4):2092-2096.

Kapitanska OS, Priadkina GO, Stasik OO et al (2016) Relationship between parameters of photosynthetic apparatus activity and yield of winter wheat under chelated microfertilizers treatment. Physiol Rast Genet. 48(6):530537. doi: 10.15407/frg2016.06.530. (in Ukrainian).

Kapitanska OS, Priadkina GA, Stasik OO (2018) The effect of foliar application of microelements carboxylate on photosynthetic pigments in winter wheat leaves. J Belarusian State University. Biology. 2:85-94. https:// journals.bsu.by/index.php/biology/article/view/2512. (in Russian).

Kaya C, Higgs D, Burton A (1999) Foliar application of iron as a remedy for zinc toxic tomato plants. J Plant Nutr. 22:12:1829-1837. doi: 10.1080/01904169909365759.

Kiriziy DA, Stasik OO, Priadkina GA et al (2014) Fotosintez: assimilyatsiya $\mathrm{CO}_{2}$ i mekhanizmy yeye regulyatsii [Photosynthesis: assimilation of $\mathrm{CO}_{2}$ and the mechanisms of its regulation] vol 2. Logos, Kyiv.

Kobayashi M, Mutoh T, Matoh T (2004) Boron nutrition of cultured tobacco BY-2 cells. IV. Genes induced under low boron supply. J Exp Bot. 55(401):1441-1443. doi: 10.1093/jxb/erh142.

Kolupaev YE (2016) Antioksidanty rastitel'noy kletki, ikh rol' v AFK-signalinge i ustoychivosti rasteniy [Plant cell antioxidants and their role in ROS signaling and plant resistance]. Advances in Current Biology. 136(2):181-198.

Kolupayev YuE, Karpets YuV, Kabashnikova LF (2019) Antioxidative System of Plants: Cellular Compartmentalization, Protective and Signaling Functions, Mechanisms of Regulation (Review). Appl Biochem Microbiol. 55:419-440. doi: 10.1134/S0003683819050089.

Kopittke PM, Lombi E, Wang P et al (2019) Nanomaterials as fertilizers for improving plant mineral nutrition and environmental outcomes. Environ Sci Nano. 6(12):35133524. doi: 10.1039/C9EN00971J.

Kosinov MV, Kaplunenko VG (2009) Pat. 38391 UA, IPC: C07C 51/41, C07F 5/00, C07F 15/00, C07C 53/126, C07C 53/10, A23L 1/00, B82B 3/00. Method of obtaining metal carboxylates "Nanotechnology for the production of metal carboxylates", Publ. 12.01.2009 [in Ukrainian].

Kromdijk J, Glowacka K, Leonelli L et al (2016) Improving photosynthesis and crop productivity by accelerating recovery from photoprotection. Science. 354(6314):857861. doi: 10.1126/science.aai8878.

Lesk C, Rowhani P, Ramankutty N(2016) Influence of extreme weather disasters on global crop production. Nature 529(7584):84-87.doi: 10.1038/nature16467.

Lichtenthaler HK (1987) Chlorophyll and carotenoids: Pigments of photosynthetic membranes. Methods in enzymology 148:350-382. doi: 10.1016/0076-6879(87)48036-1.

Liu C, Hu C, Tan $Q$ et al (2019) Co-application of moly- 
bdenum and zinc increases grain yield and photosynthetic efficiency of wheat leaves. Plant Soil Environ. 65:508515. doi: 10.17221/508/2019-PSE.

Liu DY, Liu YM, Zhang $W$ et al (2019) Zinc Uptake, Translocation, and Remobilization in Winter Wheat as Affected by Soil Application of Zn Fertilizer. Front Plant Sci. 10:426. doi: 10.3389/fpls.2019.00426.

Liu DY, Zhang W, Liu YM et al (2020) Soil Application of Zinc Fertilizer Increases Maize Yield by Enhancing the Kernel Number and Kernel Weight of Inferior Grains. Front Plant Sci 11:188. Published 2020 Feb 28. doi: 10.3389/fpls.2020.00188.

Liu H, Gan W, Rengel Z et al (2016) Effects of zinc fertilizer rate and application method on photosynthetic characteristics and grain yield of summer maize. J Soil Sci Plant Nutr. 16(2):550-562. doi: 10.4067/S0718-95162016005000045.

Long SP, Marshall-Colon A, Zhu XG (2015) Meeting the Global Food Demand of the Future by Engineering Crop Photosynthesis and Yield Potential. Cell. 161(1): 56-66. doi: 10.1016/j.cell.2015.03.019.

Long SP, Ort DR (2010) More than taking the heat: crops and global change. Curr Opin Plant Biol. 13:241-248. doi: 10.1016/j.pbi.2010.04.008.

Ma D, Sun D, Wang C et al (2017) Physiological responses and yield of wheat plants in Zinc-mediated alleviation of drought stress. Front Plant Sci. 8:1-12. doi: 10.3389/ fpls.2017.00860.

Marschner P. Marschner's Mineral Nutrition of Higher Plants (3rd Edition). London: Academic Press. 2011;672 p.

Mirzajani F, Askari H, Hamzelou $S$ et al (2013) Effect of silver nanoparticles on Oryza sativa L. and its rhizosphere bacteria. Ecotoxicol Environ. 88:48-54. doi: 10.1016/j. ecoenv.2012.10.018.

Mitin VV, Sementsov DI, Vagidov NZ. Quantum Mechanics for Nanostructures. New York: Cambridge University Press. 2010; 488 p.

Mohammadi A, Habibi D, Rohami $M$ et al (2011) Effect of drought stress on antioxidant enzymes activity of some Chickpea cultivars. AEJAES. 11(6):782-785.

Morales F, Ancin M, Fakhet D et al (2020) Photosynthetic metabolism under stressful growth conditions as a base for crop breeding and yield improvement. Plants 9(88). doi: 10.3390/plants9010088.

Morales-Díaz A, Ortega-Ortíz H. Juárez Maldonado A et al (2017). Application of nanoelements in plant nutrition and its impact in ecosystems. Advances in Natural Sciences: Nanoscience and Nanotechnology. 8(1):1-13. doi: 10.1088/2043-6254/8/1/013001.

Moreno JC, Jianing M, Agrawal S et al (2020) Expression of a carotenogenic gene allows faster biomass production by redesigning plant architecture and improving photosynthetic efficiency in tobacco. Plant J. doi: 10.1111/tpj.14909.

Morgan PB, Bolero GA, Nelson RL et al (2005) Smaller than predicted increase in aboveground net primary production and yield of field-grown soybean under fully open-air $\left[\mathrm{CO}_{2}\right]$ elevation. Glob Chang Biol. 11(10): 18561865. doi: 10.1111/j1365-2486.2005.001017.

Morgun VV, Kiriziy DA (2012) Perspektivy ta suchasni strategii polipshennya fiziologichnyh oznak pshenitsy dlya pidvycshennya productyvnosti (Prospects and modern strategies of wheat physiological traits improvement for increased productivity). Fiziologiya i biokhimiya cult rastenii. 44(6):463-48. (in Ukrainian).

Morgun VV, Rybachenko LI, Kots SY et al (2019) Features of the functioning of symbiotic systems and photosynthetic apparatus of soybean inoculated by Bradyrhizobium japonicum under the influence of metal carboxylates). Mikrobiol Z. 81(1):94-105. doi: 10.15407/microbiolj81. 01.94. (in Ukrainian).

Munné-Bosch S, Queval G, Foyer CH (2013) The impact of global change factors on redox signaling underpinning stress tolerance. Plant Physiol. 161(1):5-19. doi: 10.1104/ pp.112.205690.

Opportunities and challenges of biofuels for the agricultural sector and the food security of developing countries https://unctad.org/system/files/official-document/ditcted 20075 en.pdf.

Pariona $\bar{N}$, Martinez AI, Hdz-García HM et al (2017) Effect of hematite and ferrihydrite nanoparticles on germination and grown of maize seedlings. Saudi J Bio Sci. 24(7):1547-1554. doi: 10.1016/j.sjbs.2016.06.004.

Parry MAJ, Reynolds M, Salvucci ME (2011) Raising yield potential in wheat. II. Increasing photosynthetic capacity and efficiency. J Exp Bot. 62(2):453-467. doi: 10.1093/ $\mathrm{jxb} / \mathrm{erq} 304$.

Perez CE, Rodrigues FA, Moreira WR et al (2014) Leaf gas exchange and chlorophyll a fluorescence in wheat plants supplied with silicon and infected with Pyricularia oryzae. Phytopathology. 104(2):143-149. doi: 10.1094/ PHYTO-06-13-0163-R.

Pouri S, Motamedi H, Honary S et al (2017) Biological Synthesis of Selenium Nanoparticles and Evaluation of their Bioavailability. Braz Arch Biol Tecnol. 60: e17160452. doi: 10.1590/1678-4324-2017160452.

Presidential Commission Calls for More Ag Research. Funds. http://www.wheatworld.org/news-events/2012/12/ presidential-science-commission-calls-for-more-agresearch-funds/

Priadkina GA Physiological bases of increase of productivity of plants of winter wheat. Kyiv: Interservis. 2014:191 p. (in Ukkrainian)

Priadkina GA, Kaplunenko VG, Stasik OO et al (2014) Effect of foliar treatment by "AVATAR 1" trace element complex on the yield of grapes. Trace elements in medicine. 15(2):40-47.40_15_2.pdf. (in Russian).

Rahimizadeh M, Habibi D, Madani H et al (2007) The effect of micronutrients on antioxidant enzymes metabolism in sunflower (Helianthus annuus L.) under drought stress. HELIA. 30(47):167-174. doi: 10.2298/HEL0767147R. 


\section{PRIADKINA}

Raliya R, Nair R, Chavalmane S et al (2015) Mechanistic evaluation of translocation and physiological impact of titanium dioxide and zinc oxide nanoparticles on the tomato (Solanum lycopersicum L.) plant. Metallomics. 7:1584-1594. doi: 10.1039/c5mt00168d.

Rameshaiah GN, Jpallavi S (2015) Nano fertilizers and nano sensors an attempt for developing smart agriculture. Int $\mathrm{J}$ Eng Res Gen Sci. 3(1):314-320.

Rawashdeh H, Sala F (2014) Influence of iron foliar fertilization on some growth and physiological parameters of wheat at two growth stages. Scientific Papers. Series A. Agronomy. 2014; LVII:306-309. URL: http:// agronomyjournal.usamv.ro.

Ray DK, Ramankutty N, Mueller ND et al (2012) Recent patterns of crop yield growth and stagnation. Nat commun 3, 1293. doi: 10.1038/ncomms2296.

Read TL, Doolette CL, Cresswell T et al (2019) Investigating the foliar uptake of $\mathrm{Zn}$ from conventional and nanoformulations: A methodological study. Environ Chem. 16:459-469. doi: 10.1071/EN19019.

Reynolds M, Bonnett D, Chapman SC et al (2011) Raising yield potential of wheat. I. Overview of a consortium approach and breeding strategies. J Exp Bot. 62(2):439-452.

Reynolds MP, Ortiz-Monasterio JI, McNab A (eds) (2001) Application of Physiology in Wheat Breeding, D.F.: SYMMIT, Mexico, $246 \mathrm{p}$.

Sajedi NA, Ardakani MR, Madani H et al (2011) The effects of selenium and other micronutrients on the antioxidant activities and yield of corn (Zea mays L.) under drought stress. Physiol Mol Biol Plants. 17(3):215-222. doi: 10. 1007/s12298-011-0067-5.

Samborska-Skutnik IA, Kalaji HM, Sieczko L et al (2019). Structural and functional response of photosynthetic apparatus of radish plants to iron deficiency. Photosynthetica. doi: 10.32615/ps.2019.132.

Sanzari I, Leone A, Ambrosone A (2019) Nanotecnology in plant science: To make a long story short. Front Bioeng Biotechnol. 7:120. doi: 10.3389/fbioe.2019.00120.

Schmidt SB, George TS, Brown LR et al (2019) Ancient barley landraces adapted to marginal soils demonstrates exceptional tolerance to manganese limitation. Ann Bot. 123(5):831-843. doi: 10.1093/aob/mcy215.

Singh SK, Reddy VR, Fleisher DH et al (2017) Relationship between photosynthetic pigments and chlorophyll fluorescence in soybean under varying phosphorus nutrition at ambient and elevated $\mathrm{CO}_{2}$. Photosynthetica. 55(3):421-433. doi: 10.1007/s11099-016-0657-0.

Sokolovska-Sergiienko OG, Kapitanska OS, Priadkina GO et al (2017) Antioxidant and photoprotection systems of photosynthetic apparatus in plants of winter wheat treated with micronutrients, chelated by succinic acid. Physiol Rast Genet. 49(5):434-443. doi: 10.15407/frg 2017.05.434. (in Ukrainian).

Stasik OO, Pryadkina GO, Kiriziy DA et al (2020) Effect of foliar treatment with microelement complex, obtained by nanotechnology, on the photosynthetic activity of winter wheat plants under different moisture. Physiol Rast Genet. 52(1):46-63. doi: 10.15407/frg2020.01.046. (in Ukrainian).

Sun T, Yuan H, Cao H et al (2018) Carotenoid Metabolism in Plants: The Role of Plastids. Molecular Plant. 11(1):5874. doi: 10.1016/j.molp.2017.09.010.

Sun $X, H u C$, Tan $Q$ et al (2006) Effects of molybdenum on photosynthetic characteristics in winter wheat under low temperature stress. AAS. 32(9):1418-1422.

Taran N, Storozhenko V, Svietlova N et al (2017) Effect of zinc and copper nanoparticles on drought resistance of wheat seedlings. Res Lett. 12(1):60. doi: 10.1186/s11671017-1839-9.

Torabian S, Zahedi M, Khoshgoftar AH (2016) Effects of foliar spray of two kinds of zinc oxide on the growth and ion concentration of sunflower cultivars under salt stress. J Plant Nutr. 39(2):172-180. doi: 10.1080/01904167.2015.1009107.

Torun B, Tolay I, Erdem H et al (2017) Effects of SeedZinc Priming on SPAD Values, Dry Matter Yields and Zinc Concentrations of Maize Plants under Greenhouse Conditions. In: XVIII International Plant Nutrition Colloquium, Copenhagen, Denmark, 19-24 Aug 2017.

Tränker M, Tavakol E, Jakli B. (2018) Functioning of potassium and magnesium in photosynthesis, photosynthate translocation and photoprotection. Physiol Plant. 163(3):414-431. doi: 10.1111/ppl.12747.

URL: https://ec.europa.eu/jrc/en/science-update/forecastingwheat-yields-under-extreme-weather-conditions. (last update 18.10.2018).

Vardhini BV, Anjum NA (2015) Brassinosteroids make plant life easier under abiotic stressed mainly by modulated major components of antioxidant defense system. Front Plant Sci. 2(67):1-16. doi: 10.3389/fenvs.2014.00067.

Vatansever R, Ozyigit II, Filiz E (2017) Essential and Beneficial Trace Elements in Plants, and Their Transport in Roots: a Review. Appl. Biochem. Biotechnol .181:464482. doi: 10.1007/s12010-016-2224-3.

Verbruggen N, Hermans C (2013) Physiological and molecular responses to magnesium nutritional imbalance in plants. Plant Soil. 368:87-99. doi: 10.1007/s11104-013-1589-0.

Wang JW, Mao H, Zhao HB et al (2012) Different increases in maize and wheat grain zinc concentrations caused by soil and foliar applications of zinc in Loess Plateau, China. Field Crops Re. 135:89-96. doi: 10.1016/j.fcr.2012.07.010.

$W u$ S, Hu C, Tan $Q$ al (2017) Nitric oxide mediates molybdenum-induced antioxidative defense in under drought stress. Front Plant Sci. 8:1085. doi: 10.3389/ fpls.2017.01085

Wu SW, Hu CX, Tan QL et al (2014) Effects of molybdenum on water utilization, antioxidative defense system and osmotic-adjustment ability in winter wheat (Triticum aestivum) under drought stress. Plant Physiol Biochem. 83:365-374. doi: 10.1016/j.plaphy.2014.08.022. 


\section{INFLUENCE OF TRACE ELEMENTS, APPLIED IN CLASSICAL AND NANO FORMS}

Yu $M$, Ни C, Wang $Y$ (2006) Effects of molybdenum on the intermediates of chlorophyll biosynthesis in winter wheat cultivars under low temperature. Agr Sci China. 5(9):670-677. doi: 10.1016/S1671-2927(06)60109-0.

Zander P, Amjath-Babu TS, Preissel S et al. (2016) Grain legume decline and potential recovery in European agriculture: a review. Agron Sustain Dev 36(26). doi: 10.1007/s13593-016-0365-y.

Zhang FS, Chen XP, Vitousek $P$ (2013) Chinese agriculture: An experiment for the world. Nature. 497(7447):33-35. doi: $10.1038 / 497033$.

Zhang $F$, Chen $J$ A paradigm of nutrient management for fertilizer industry and global society In: XVIII
International Plant Nutrition Colloquium, Copenhagen, Denmark, 19-24 Aug 2017. P. 79-80.

Zhang M, Hu C, Zhao Xet al (2012) Molybdenum improves antioxidant and osmotic-adjustment ability against saltstress in Chinese cabbage (Brassica campestris L. ssp. Pekinensis). Plant Soil. 355(1-2):375-383. doi: 10.1007/ s11104-011-1109-z.

Zhu XG, Long SP, Ort DR (2010) Improving photosynthetic efficiency for greater yield. Annu Rev Plant Biol. 61:235261. doi: 10.1146/annurev-arplant-042809-112206.

Zhu XG, Ort DR, Parry $M$ et al (2020) A wish list for synthetic biology in photosynthesis research. J Exp Bot. eraa075. doi: 10.1093/jxb/eraa075.

\section{ПРАВИЛА ДЛЯ АВТОРІВ}

У журналі «Agricultural Science and Practice» публікуються результати фундаментальних досліджень з питань агрономії, біології, біотехнології та біоінженерії, ветеринарної медицини.

Друкуються фундаментальні статті, огляди літератури, короткі повідомлення, які раніше не видавалися. Особливо просимо уникати технічного плагіату та самоплагіату. Редакція дуже уважно відслідковує ці моменти.

Рукописи надсилаються на конфіденційне рецензування спеціалістам відповідної галузі.

За умови позитивної рецензії з рукописом знайомиться науковий редактор - конфіденційно.

Статті надсилаються українською/російською мовою, перекладаються в редакції безкоштовно і публікуються лише англійською мовою; резюме - українською мовою. В електронній версії журналу (http://www.agrisp.com) з 2014 p. розміщуються резюме, список літератури і повний текст статей англійською мовою (окрім поточного року).

Кожній статті присвоюється цифровий ідентифікатор (DOI), що сприяє коректному розповсюдженню матеріалу статті в мережі Інтернет.

Комплект документів, необхідних для реєстрації статті.

Електронною поштою надсилаються:

- лист - направлення від організації (pdf);

- договір про передачу авторських прав (pdf), оформлений та підписаний окремо кожним із співавторів, наприклад, 4 автори -

4 договори (зразок договору на сайті журналу);

- звертаємо Вашу увагу на те, що договір про передачу авторських прав набуває чинності після прийняття статті

до публікації. У разі відхилення Вашої статті редколегією журналу договір автоматично втрачає силу. Підписання договору автором (авторами) означас, що він (вони) ознайомлений та згодний з умовами договору;

- рукопис подається doc, docx; ілюстрації; таблиці.

Статті обов'язково супроводжуються українсько-англійським словником специфічних термінів (не менше 30), використаних у статті.

\section{Рукопис має містити:}

- індекс УДК;

- назву статті англійською й українською мовами;

- прізвища та ініціали всіх авторів двома мовами;

- назву і поштову адресу(и) з індексами установ(ви), де працює(ють) автор(и), двома мовами;

- електронну пошту всіх авторів, автора для листування позначити зірочкою.

Структуровані резюме англійською та українською мовами повинні мати ідентичний зміст (кожне не менше 1500 знаків 3 пробілами). Структура резюме: Мета. Методи. Результати. Висновки. Ключові слова.

Не можна в резюме копіювати речення з розділів статті - перефразуйте їх. Резюме - це основні положення Вашої наукової роботи. Це Ваша реклама, ї̈ прочитають тисячі науковиів у різних базах даних-тому вона повинна бути зрозумілою, вичерпною, особливо пункт "методи". 